\title{
Susan Birkenseer
}

\section{The American Civil War}

\section{A collection of free online primary sources}

$\mathbf{T}$ he American Civil War began in 1861, lasted until 1865, and was ruinous by any standard. Within months of President Lincoln's inauguration, seven southern states began the secession from the Union and declared the Confederate States of America. This split in the fabric of the country began a bitter war, concluding in the death of more than 750,000 soldiers. When the South finally surrendered, the Confederacy collapsed, and slavery was abolished. To understand the conflict, take a look back at the primary documents that highlight decisions of generals, the everyday drudgery of soldiers, and the photographic images of battle.

Hundreds of websites offer insight into the American Civil War. This guide is not comprehensive, but it highlights a diverse collection of free websites of primary sources for the study of the war. These websites include digitized newspaper archives for both the Union and Confederate sides of the struggle, collections of letters and diaries, digitized photographs, maps, and official records and dispatches from the battlefields.

\section{Newspapers}

- Brooklyn Daily Eagle (1841-1955). An important daily newspaper, the Eagle was unusual for its time since it covered national as well as regional news. The archive is searchable, can be browsed by date, and includes zooming capabilities to see the tiny text up close. The archive is maintained by the Brooklyn Public Library. Access: http://bklyn.newspapers.com/title_1890/the _brooklyn_daily_eagle/.

- Chronicling America. This site offers access to multiple newspapers from both the Confederate and Union states. Over 1,400 newspapers are in the archive, but not all of them are from the Civil War years. Examples of newspaper titles include: Memphis Appeal (1857-1886), Chattanooga Rebel (1862-1865), New York Sun (1859-1916), and New York Daily Tribune (1842-1866). Search across the newspapers for a range of contemporary stories from both sides of the war. From the Library of Congress. Access: http://chroniclingamerica.loc.gov/\#tab=tab_newspapers.

- Harper's Weekly. The archive of this popular weekly newspaper highlights only the Civil War years. The site is searchable and is arranged chronologically with thumbnails of the front pages. All pages from the 18611865 Civil War

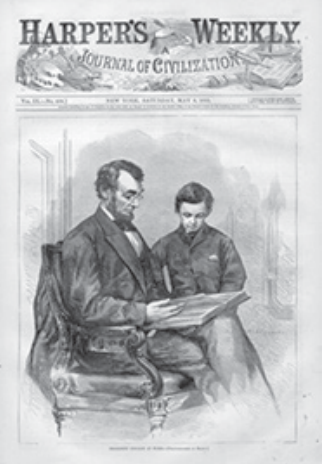

Susan Birkenseer is reference and instruction librarian at Saint Mary's College of California, email: sbirkens@ stmarys-ca.edu

(c) 2015 Susan Birkenseer 
period have been scanned including the engravings and illustrations. From the Lee Foundation. Access: http://www. sonofthesouth.net/leefoundation/the -civil-war.htm.

- Richmond Daily Dispatch (18601865). This paper was published from the Confederate capital and has a digitized and searchable online archive of 1,384 issues. The site is funded by the Institute of Museum and Library Services. Access: http://dlxs.richmond. $\mathrm{edu} / \mathrm{d} / \mathrm{ddr} /$ index.html.

- Secession-Era Editorials. This site from the Furman University history department in South Carolina contains transcribed editorials from contemporary newspapers, all from the 1850s. The specific issues discussed are the Nebraska Bill debates, the caning attack on Senator Charles Sumner by Representative Preston Brooks, John Brown's Raid on Harper's Ferry, and the Dred Scott decision. These events all highlight the varied and inflexible opinions of their time from both sides of the conflict. Access: http:// history.furman.edu/editorials/see.py.

\section{Maps and photographs}

- Civil War Glass Negatives and Related

Prints. Approximately 7,000 portraits and battleground images are available. The collection is from the glass negatives of Mathew Brady and Alexander Gardner, as well as from photographic collections that were purchased by the Library of Congress in 1943. Browse by broad subjects or search by keyword. Access: http://www.loc.gov/pictures/collection/cwp/.

- Civil War Maps. Nearly 3,000 maps are included in this online composite of three collections from the Library of Congress, the Virginia Historical Society, and the Library of Virginia. Search by keyword and narrow with the facets to the left of the results page. Access: http://www.loc.gov/collection /civil-war-

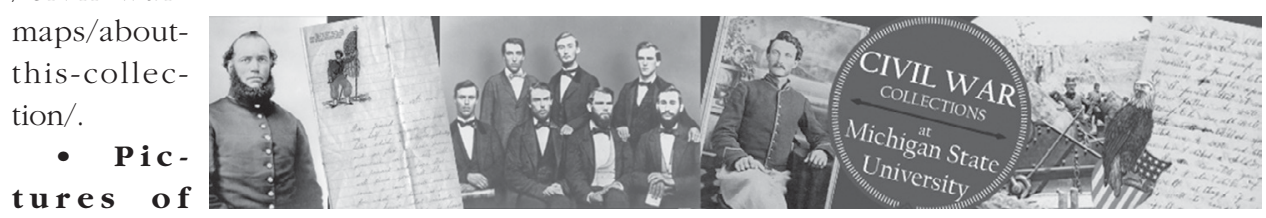
raphy brought the battles home during the American Civil War. The National Archives has organized the Mathew Brady and Alexander Gardner photographs into broad categories for easy browsing. Access: http://www.archives.gov/research/military /civil-war/photos/index.html.

\section{Diaries and letters}

- Abraham Lincoln Papers at the Library of Congress. Approximately 20,000 documents, which include correspondence with enclosures of newspaper clippings, drafts of speeches, notes, pamphlets, and other printed material by Lincoln, are available. Most of the material dates from the presidential years. Lincoln had a lively correspondence with many people in his day, so this is a rich resource. Each piece is scanned, with accompanying transcription. Searchable by keyword or just browse the collection. Access: http://memory.loc.gov/ammem/alhtml /malhome.html.

- American Civil War Collection at the Electronic Text Center. This site has transcribed letters from the University of Vircollections (some links are only accessible by University of Virginia students). Access: http://etext.virginia.edu/civilwar/.

- The Civil War Archive: Letters Home from the Civil War. A collection of letters from both Union and Confederate soldiers, organized by name and regiment. Access: http://www.civilwararchive.com /LETTERS/letters.htm.

- The Civil War Collection at Michigan State University. A huge online collection of scanned letters, newspaper articles, images, photographs, diaries, and much more, filled with the stories of Michigan soldiers. Access: http://civilwar.archives.msu.edu/. ginia special collections with links to other 
- The Civil War Collection at Penn State. Penn State has a rich digitized special collection. These include diaries, newspapers, and other ephemera. No transcriptions are available for the diaries, but the scanned pages are clean and easy to peruse. Access: http://www.libraries.psu.edu/psul/digital /civilwar.html.

- Civil War Diaries and Letters. Browse a list of scanned diaries and letters from the University of Iowa Libraries, some of which currently have transcriptions, but not all. You can also browse by year to get the materials for a particular time. Access: http://digital.lib.uiowa.edu/ $\mathrm{cwd} /$.

- Civil War Diaries and Letters Collections. A collection of diaries and letters from Auburn University, covering both sides of the war; each item is scanned and transcribed. Access: http://diglib.auburn.edu/collections /civilwardiaries/.

- Civil War on the Western Border: The Missouri-Kansas Conflict, 1855-1865. A collection of letters, photographs, and diary entries that document a lesser-known conflict of

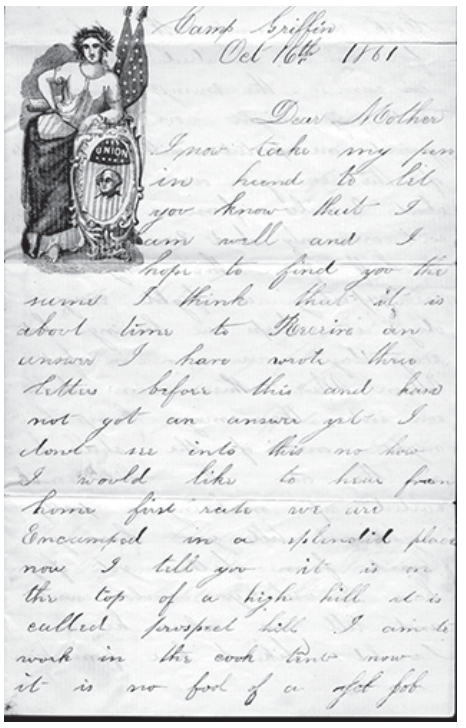

describing their living conditions in the South. Access: http://guides.library.duke.edu / content.php?pid=41224\&sid=303304.

- First Person Narratives of the American South. Everyday people's voices speak through their diaries, autobiographies, exslave accounts, and memoirs on this site, which is organized alphabetically or by subject. Access: http://docsouth.unc.edu/fpn /index.html.

- Manuscripts of the American Civil War. This special collection from the University of Notre Dame's Rare Books and Special Collections contains seven soldier's diaries, which have been carefully scanned and transcribed. The soldiers represented are from both sides of the war. The diaries highlight their day-to-day experiences-from the mundane to the terrifying. Access: http://www.rarebooks. nd.edu/digital/civil_war /diaries_journals/.

- Saint Mary's College of California Special Collections. Saint Mary's College has a small, select special collection containing letters from a private in the Fifth Vermont regithe time. The resources are scanned and transcribed. When possible, the letters also show connections to other related people and events. This site is a result of collaboration with Kansas City-area libraries, historical societies, and museums. Access: http://www. civilwaronthewesternborder.org/.

- The Civil War: Women and the Homefront. Duke University has put together this study guide relating to women's role during the war. Use the tab labeled "Primary Sources Online," which includes digitized diaries and letters, as well as outside links to other institutions' collections. The online papers include a collection from Rose O'Neal Greenhow, a famed Confederate spy. Other letters include those written by African American slaves, ment, and a diary from a captain of the Sixteenth Michigan regiment. The collections are digitized and transcribed, and the site is well illustrated. Access: http://www. stmarys-ca.edu/library/about-the-library /special-collections.

- South Carolina and the Civil War. The site brings together primary sources by eyewitnesses from the holdings of the University of South Carolina. Included on the site are diaries, sheet music, maps, letters, and photographs. The collections are scanned and viewable, but with little transcription or description. Access: http://library.sc.edu /digital/collections/civilwar.html.

- Valley of the Shadow. Thousands of documents are accessible that compare life 
in two towns during the war: one in Virginia and one in Pennsylvania. These documents include letters, diaries, maps, newspaper accounts, and other sources. Access: http:// valley.lib.virginia.edu/.

- Virginia Military Institute Archives. The Virginia Military Institute has a proud history of training its students to serve in the military service of the United States. The archives provide access to the full-text of more than 75 letters, diaries, manuscripts, and other ephemera of soldiers from both armies. Access: http://www.vmi.edu/Archives/Civil _War/Civil_War_Resources_Home/.

- Wisconsin Goes to War: Our Civil War Experience. The University of Wisconsin is in the process of digitizing letters, diaries, poetry, and other writings from Wisconsin's soldiers; approximately 630 pages to date, with an expected completion number to be more than 2,600 pages. Access: http:// uwdc.library.wisc.edu/collections/WI/WIWar.

\section{Dispatches and battles}

- Antietam on the Web. This site looks at the crucial Battle of Sharpsburg (Antietam), highlighting generals and other officers, battle maps, and important background information. This site also includes the transcriptions of reports from the officers from both sides of the war, as well as excerpts from diaries and letters of some of the soldiers who survived. Access: http:// antietam.aotw.org/index.php.

- Making of America: Official Records of the Union and Confederate Navies. The Making of America site is an excellent source of primary documents, and this one features the orders, reports, and correspondence from the Union and Confederate navies. The scanned pages of the 30 -volume set from the Government Printing Office are annotated and arranged chronologically. The collection is searchable. This is an essential resource for any study of naval operations in the war. Access: http://ebooks.library.cornell.edu/m /moawar/ofre.html.

- Ulysses S. Grant Presidential Library. This site from Mississippi State University contains the first 31 volumes of The Papers of Ulysses S. Grant published by Southern Illinois University Press, and includes his military papers from the Civil War. Also included are photographs and prints from the life of Grant, including photographs from the war. The volumes are searchable as well as browsable. Access: http://digital.library.msstate.edu/cdm /usgrantcollection.

- The War of the Rebellion: A Compilation of Official Records of the Union and Confederate Armies. This 70-volume work from the Making of America site at Cornell University contains the formal reports for both the Union and Confederate armies, including correspondence and orders. The scanned volumes are arranged chronologically and identified with a brief annotation. The volumes are searchable. This is an essential resource for anyone doing serious research on battles, regiments, and the progress of the war. Access: http://digital.library.cornell. $\mathrm{edu} / \mathrm{m} / \mathrm{moawar} /$ waro.html.

\section{Slavery and abolitionism}

- Born in Slavery: Slave Narratives from the Federal Writers' Project, 19361938. Includes more than 2,300 first-person accounts, and more than 500 photographs. The narratives were collected in the 1930s by the Federal Writer's Project and the Works Progress Administration, and put into a seventeen volume set. Access: http://memory.loc. gov/ammem/snhtml/snhome.html.

- Frederick Douglass Papers. A former slave and devout abolitionist, Douglass's papers were digitized by the Library of Congress. They are searchable, and also can be browsed by date, and then narrowed by type, such as speeches or correspondence. Access: http://www.loc.gov/collection/frederick -douglass-papers/about-this-collection/.

- North American Slave Narratives. The University of North Carolina-Chapel Hill has a special collection dedicated to slave narratives. Not every manuscript is a primary document, but many are. Included on the site are narratives of fugitive and former slaves in published form from before 1920. For 
scholars interested in further study, a bibliography of slave and former-slave narratives by William L. Andrews is also included. Access: http://docsouth.unc.edu/neh/index.html.

- Slavery and Abolition in the U.S.: Select Publications of the 1800s. Reflecting both sides of the slavery question, these publications from the 1800s include speeches, tracts, pamphlets, books, legal proceedings, religious sermons, and personal accounts. This collection from a cooperative project by Millersville University and Dickinson College includes more than 24,000 individual pages. Access: http://deila.dickinson.edu /slaveryandabolition/index.html.

- Slaves and the Courts 1740-1860.

From the Library of Congress's American Memory Project this site consists of trials and cases, arguments, proceedings, and other historical works of importance that relate to the prosecution and defense of slavery as an institution. The collection contains more than 100 pamphlets and books published between 1772 and 1889. Access: http://memory.loc. gov/ammem/sthtml/.

\section{Confederacy}

- The Museum of the Confederacy. Various primary sources are accessible, including a collection of photographs, documents, and artifacts relating to Lee and Jackson, the "Roll of Honor and Battle Accounts" from Confederate soldiers, and a searchable database of their collections. Access: http://www.moc. org/collections-archives? mode $=$ general .

- The Papers of Jefferson Davis. A selection of documents from the published papers of the same name that includes speeches, reports, and correspondence. The documents are organized by volume with brief annotations. Access: http://jeffersondavis.rice.edu /documentslist.aspx. $\boldsymbol{n}$

"Redeveloping a course...," (cont. from page 250)

not seem receptive. They were appropriately skeptical about social media conversations and their role in research, accurately noting that anonymity often makes it hard to evaluate the legitimacy of comments on articles and blogs. However, I wanted them to better understand that authority does not need to be hierarchical, that experts do engage with material outside of peer-reviewed publishing channels.

Students were required to think about the kinds of sources they would use, and what they would expect to find there, before actually searching for material to answer their research questions. This was new from previous semesters. I was impressed that they identified a wide array of sources - from government documents to political blogs. However, they didn't always accurately identify what they could expect to find there. One student thought she would find statistics in an academic journal, for instance. As other librarians have noted, this disconnect between students' expectations and real- ity accounts for much of the frustration in student research. This is an area to address with later classes.

While these informal observations are not assessment data, they have helped me plan for the next time I teach this course. I do believe that the framework has made an impact on this small group of LIB 201 students. I saw them grappling conceptually with ideas of authority and scholarly conversation, as well as with discrete skills like using a subject thesaurus. The conceptually based framework is more aligned with our profession's current thinking than the standards. It is harder to translate broad concepts into course objectives, assignments, and activities. Yet, this should not stop instructors from undertaking the task. In my experience, the process required deeper reflection, a greater internalization of the concepts found in the frames, lots of reading, and much trial and error-basically the kind of work that we expect of our students. $\boldsymbol{n}$ 